\title{
ARTICLE \\ A Comparative Study of Humanistic Exchange and Cooperation be- tween China and Southeast Asian in the Perspective of "the Belt and Road" Initiative
}

\section{Zhihong Wen*}

Shanghai International Studies University, Shanghai, 200083, China

\begin{tabular}{l} 
ARTICLE INFO \\
\hline Article history \\
Received: 2 March 2021 \\
Accepted: 15 March 2021 \\
Published Online: 31 March 2021 \\
\hline Keywords: \\
Relationship between China and South-east \\
Asia \\
Confucius institute \\
Sister cities \\
Tourism cooperation \\
"the Belt and Road" Initiative \\
Humanistic exchange
\end{tabular}

\section{Introduction}

Southeast Asia is located in the southeast of Asia, the Indian Ocean in the west, the Pacific Ocean in the east, Oceania in the south, China and India in the north, and is located in Asia and Oceania, the Pacific Ocean and the Indian Ocean "crossroads ". Because of its superior geographical location, Southeast Asia is of great significance to the implementation of the "Belt and Road" policy in China, and Southeast Asian countries are also the natural partners and priority directions for the construction of the

\section{ABSTRACT}

In the exchanges between different countries, apart from enhancing political mutual trust and strengthening pragmatic cooperation, it is of great importance to forging humanistic exchange. With a long history of exchanges between China and all the countries in South-east Asia, the humanistic exchange between China and South-east Asia has been continuing since the founding of the People's Republic of China. After the establishment of China-ASEAN dialogue relations, the strategic position of humanistic exchange has been rapidly improved. By means of the case study of Confucius Institute, sister cities, and tourism cooperation, the author has found that humanistic exchange between China and South-east Asia has enjoyed a long history and embodied profound and extensive meaning. It is the ancient Maritime Silk Road that helped to form the exchanges between China and South-east Asia. In the meantime, it is the 21st-Century Maritime Silk Road that has deepened this friendship. The successful experience of humanistic exchange and cooperation between China and South-east Asia has not only consolidated the China-ASEAN strategic partnership but also provided a conducive reference for people-to-people ties in the implementation of the Belt and Road Initiative. In addition, it has added dynamics and confidence to the building of a community with a shared future for mankind which is propelled by China's humanistic diplomacy.

"21st Century Maritime Silk Road "in China.

2. Overview of the History of Humanistic Exchange between China and Southeast Asian Countries

\section{1 "Maritime Silk Road" and Humanistic Ex- change between Ancient China and Southeast Asian Countries}

In history, the development of the Maritime Silk Road

*Corresponding Author:

Zhihong Wen,

Shanghai International Studies University, Shanghai, 200083, China;

E-mail:sisuwzh@163.com 
is divided into four main stages: one is the opening period from the pre-Qing Dynasty to the Han Dynasty; the other is the development period from Wei, Jin to Sui, and Tang dynasties; the third is the prosperity period from Song Dynasty to Yuan Dynasty; and the fourth is the period from the Ming Dynasty to the Qing Dynasty.

After Zhu Di's accession to the throne in 1402, in order to strengthen his contacts with the countries of the Southern Ocean, Zheng He was sent from 1405 to lead the world's most advanced and largest fleet, leading a large number of people and carrying large quantities of goods.

On the political level, compared with the spontaneous formation of the "land Silk Road" to promote trade exchanges and civilized dialogue between China and foreign countries, the "maritime Silk Road" opened by Zheng He's fleet has a clear political purpose, expanding and deepening friendly relations between China and neighboring countries and Asian-African countries along the way, and has become the historical source of China's practice of "peaceful diplomacy" thought. On the economic level, Zheng He's seven voyages to the West to a certain extent led to the development of "tribute trade" between China and foreign countries. Because of the large size of Zheng He's fleet, every time he goes to sea, he will transport goods used for overseas trade and carry out official trade in addition to carrying a large number of reward items. Therefore, the "tribute trade" formed by Zheng He's voyage to the West greatly enriched the scale and types of Sino-foreign trade at that time. On the cultural level, Zheng He's voyage to the West promoted the exchange and spread of Buddhism, Islam, and other religions in Southeast Asia. Although the religious and humanistic exchange was not the main purpose of the Ming Chengzu's dispatch of Zheng he to the Western Ocean, Zheng he himself attached importance to it and even formed "Zheng He belief" and built places of worship in some areas, such as Siam Sanbao Temple, Javanese Sanbao Temple, Da Jue Temple, etc. Zheng He realized the first real and active religion in the history of the country to "go out ".

In addition, Zheng He also played a direct impact on the formulation and implementation of the policy of overseas Chinese in the Ming Dynasty. During Zheng He's voyage to the West, he found that there was a huge difference between the court's cognition and the actual situation of the expatriates. Overseas Chinese not only did not respond to the court's appeal, but also divided into two groups: Chinese Muslim groups mainly from Fujian (especially Quanzhou), Guangdong, Yunnan and Hainan, and Chinese folk religions mainly from Guangdong and Fujian. On this basis, Zheng He formulated a policy of flexible consideration of the interests of overseas Chinese, set up a special organization responsible for the management of overseas Chinese in Southeast Asia, and cooperated with Zheng he in political and economic support during his voyage to the West, so that the social status and image of overseas Chinese were promoted.

\subsection{Humanistic Exchange between China and Southeast Asian Countries between 1949 and 1991}

The countries of Southeast Asia are close neighbors of China. As early as 2000 years ago, they began to exchange humanities, have profound influence on each other in religion, art, literature and so on, and have established traditional friendly relations with each other.

After the founding of New China, in Southeast Asia, China first established diplomatic relations with Vietnam, Indonesia, and Myanmar, and began close humanistic exchange. In the 1950s, China and Vietnam signed a cultural cooperation agreement, and mutual humanistic exchange were very frequent. In addition to the exchange of visits by government cultural delegations, writers and professional delegations of fine arts, China sent an art troupe to Vietnam to visit and perform almost every year. During the same period, China's humanistic exchanges with Myanmar, Indonesia, and Cambodia were also quite active. A Chinese cultural delegation headed by Ding Xilin, Deputy Minister of Culture (in the second half of 1951), a large Chinese art troupe led by Zheng Zhenduo, Deputy Minister of Culture (in January 1955, performing songs, dances, and Peking Opera) and many cultural and friendly people visited Myanmar. Chinese culture, writers, Buddhist delegations and art groups visited Indonesia and Cambodia, and similar delegations from these countries visited China one after another. During this period, China and Thailand, which has not yet established diplomatic relations, also began folk humanistic exchange.

In the 1960s, China signed cultural agreements with Indonesia and Cambodia, and its humanistic exchange projects increased. From 1961 to 1965, there were 9 delegations from Indonesia to China, including films and friends associations, and 4 from similar delegations from China to Indonesia. From 1960 to 1967, four Chinese art groups visited Cambodia. At the same time, Cambodian art troupes also visited China many times. But after the beginning of the Cultural Revolution, China's humanistic exchange with Southeast Asian countries basically stopped, and humanistic exchanges with Indonesia were interrupted.

In the mid-1970s, China resumed humanistic exchange with most countries in Southeast Asia. In the late 1970s, 
China had close cultural contacts with the Philippines and Thailand, and signed a cultural agreement with the Philippines in 1979. In addition, from 1975 to 1979, China visited Singapore, where diplomatic relations had not yet been established, and Malaysia, where humanistic exchanges were less frequent. China suspended cultural relations with Cambodia and Vietnam due to the change of political situation in Cambodia in 1970 and other well-known reasons.

From 1980 to 1991, China entered a new stage of humanistic exchange with Southeast Asian countries, and signed an annual cultural cooperation implementation plan with most of them. The projects exchanged between the two sides were not only wide in scope, but also increased in number and specifications. During this period, government cultural delegations led by Minister of Culture Huang Zhen, Zhu Muzhi, Wang Meng, acting Minister he Jingzhi, Vice Minister Yao Zhongming, Lu Zhiguang and Liu Deyou visited Thailand five times, the Philippines and Myanmar three times each, and also visited Malaysia, Singapore and Laos. China sent to the Philippines to visit more than 10 art troupes, Thailand, Singapore art troupes each 20. In the same period, government cultural delegations and art troupes led by the ministers of culture of most Southeast Asian countries also visited China many times. As for the exchange of visits of writers and films, radio and television, news, education, sports and other delegations are numerous. In addition, a number of film festivals and art exhibitions have been held with most countries in South-East Asia. Over the years, through a variety of humanistic exchange, China and Southeast Asian countries to enhance friendship and mutual understanding.

\subsection{Humanities Exchange after China and ASE- AN Establish Dialogue Relations}

China and ASEAN established a dialogue relationship in 1991 and signed the Joint Declaration of the People's Republic of China and ASEAN Leaders in 2003 and announced the establishment of a "strategic partnership for peace and prosperity ". ${ }^{[1]}$ In the early 21 st century, multilateral cooperation on the platform of international organizations has become a new focus of our diplomatic work. The strategic partnership between China and ASEAN for peace and prosperity is an important diplomatic practice under this background. In order to clarify the specific content of the cooperation, in 2003, the two sides signed the Action Plan for the Implementation of the Joint Declaration of China-ASEAN Strategic Partnership for Peace and Prosperity (2005-2010). In the next 10 years, To continue to deepen China-ASEAN strategic partner- ship for peace and prosperity, Supporting ASEAN as an ASEAN community in 2015, The two sides signed the Action Plan for the Implementation of the Joint Declaration on China-ASEAN Strategic Partnership for Peace and Prosperity (2011-2015); To promote a peaceful, stable, integrated, prosperous and caring ASEAN community, The two sides signed the Action Plan for the Implementation of the Joint Declaration of China-ASEAN Strategic Partnership for Peace and Prosperity (2016-2020). The main areas involved in human exchanges include: scientific and technological cooperation, cultural cooperation, educational cooperation, local government cooperation and folk exchanges.

Since the establishment of China-ASEAN dialogue relations, the two sides have created a series of cooperation platforms, such as the China-ASEAN Exposition, the China-ASEAN Center, the China-ASEAN Environmental Protection Center, and the China-ASEAN Education Exchange week. Cooperation mechanisms have been established in about 11 fields, close human exchanges and cooperation have strengthened the foundation of bilateral friendship and brought tangible benefits to the people of both sides. ${ }^{[2]}$ Over the past 28 years, China and ASEAN have carried out multi-level and multi-channel humanistic exchange and cooperation through ministerial meetings, forum discussions, personnel exchanges, art festivals and exhibitions, which have greatly enhanced the understanding, respect and appreciation of each other's cultures by China and ASEAN and laid a solid foundation for the development of China-ASEAN relations. ${ }^{[3]}$ Since 2005, China and ASEAN have identified culture as a key area of cooperation. In recent years, from the office to the folk, China and ASEAN have cooperated frequently in the cultural industry, festival and exhibition, language education and training, tourism, sports, performing arts and so on, and the field of humanistic exchange has been expanding. ${ }^{[4]}$

In addition, China and ASEAN countries have conducted multi-level and multi-field exchanges and discussions to enhance mutual understanding. The year 2016 marks the 25th anniversary of China-ASEAN dialogue and the year of educational exchange. The two sides have launched a series of activities to promote youth exchanges and development, including the ASEAN Student Games, the Youth Humanities Forum, the Youth Leaders Summit in Colleges and Universities, and youth summer camps. Building on China-ASEAN youth exchange activities, support for ASEAN student activities, exchange activities between China-ASEAN vocational education institutions, China-ASEAN Education Exchange Week and cooperation projects organized by Southeast Asian Ministers of 
Education, China-ASEAN Language and Culture Center, Chinese Language and Culture Education Base, Education and Research Network and Association for Cooperation and Exchange of Engineering Universities have been set up one after another. ${ }^{[5]}$

In general, China established stable ties with Southeast Asian countries through land and sea trade during the Han Dynasty. With the development of navigation technology, Zheng He, a navigator of the Ming Dynasty, built a far-reaching maritime trade network between China and Southeast Asian countries. Economic and trade cooperation opened a new chapter, and population mobility reached a peak in this period. Since the founding of New China, China and Southeast Asian countries have been increasingly close in humanistic exchange. In all kinds of documents signed, the importance of humanistic exchange has gradually increased, especially in the field of education cooperation has established a close cooperative relationship.

\section{Comparison of China's Major Projects on Human Exchange in Southeast Asia}

\subsection{Education Exchange Confucius Institute}

Confucius Institute, Confucius classroom is a non-profit educational institution established in our country in cooperation with foreign universities, middle schools and other educational organizations. It is a new educational model. With the increasing political, economic and cultural strength of China, Confucius Institute, as a Chinese language and Chinese culture promotion organization, has received more and more attention. Since the establishment of the first Confucius Institute in Seoul, South Korea in 2004, as of June 2019,539 Confucius Institutes and 1129 Confucius classrooms have been established worldwide, covering 155 countries and regions in Asia, the Americas, Europe, Africa and Oceania. ${ }^{[6]}$

Southeast Asia has a special geographical location. The 11 countries in Southeast Asia are connected by land with our country by Myanmar, Laos, Vietnam, Thailand and so on. The countries connected by sea with our country are Philippines, Malaysia, Indonesia, Brunei and so on. These countries have a deep relationship with China, have lasted for thousands of years in economic, trade and humanistic exchange, and Southeast Asia is the most Chinese and overseas Chinese region in the world. However, according to the official figures released by the National Han Office, the number of Confucius Institutes and Confucius classrooms in Southeast Asia is relatively small and uneven compared with Europe, America and East Asia. (See Figure 1)

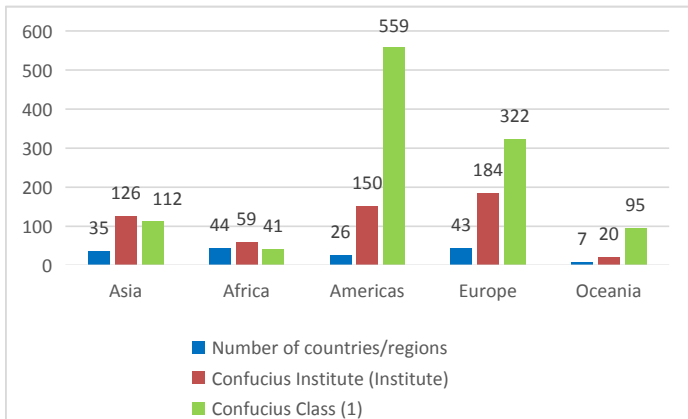

Figure 1. Global distribution of Confucius Institutes ${ }^{[6]}$

As of June 2019, Of the 11 countries in South-East Asia, With the exception of Brunei and East Timor, which did not have Confucius Institutes (classrooms), Other countries have established 37 Confucius Institutes and 17 Confucius classrooms (including those to be launched). (See Figure 2) Quantitatively, Thailand has the largest number of Confucius Institutes, Confucius Class (11), Indonesia ranks second, third in the Philippines, Malaysia fourth, Laos, Cambodia, Singapore, Vietnam one each.

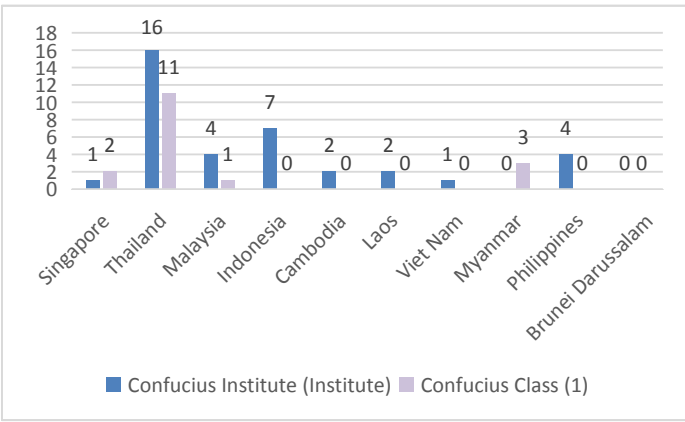

Figure 2. Distribution of Confucius Institutes and Confucius Classes in Southeast Asia ${ }^{[6]}$

As of December 31,2018, January 2006 to December 2018, in 13 years ,34 Confucius Institutes were established in Southeast Asia, 11 in 2006, No new Confucius Institutes have been established in Singapore, Cambodia and Laos since 2010; No new Confucius Institutes were established in Southeast Asia between 2011 and 2013. (See Figure 3) ${ }^{[7]}$

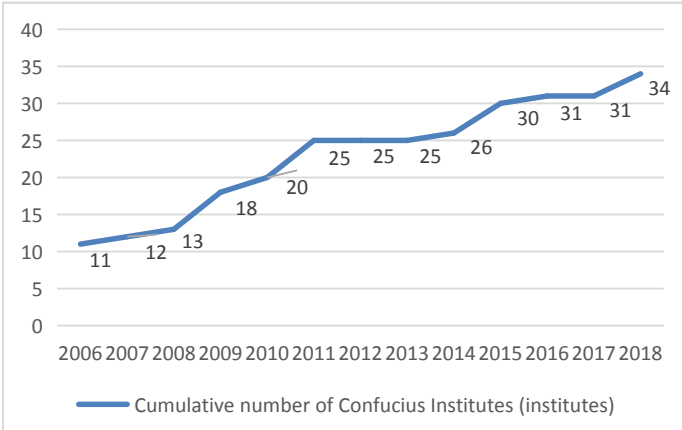

Figure 3. Annual and Cumulative Number of Confucius Institutes in Southeast Asia ${ }^{[7]}$ 
From the historical and cultural point of view. During the Han Dynasty, China established stable ties with Southeast Asian countries through land and sea trade. During the prosperous Tang Dynasty, the two sides exchanged more frequently. With the development of navigation technology, Zheng He, a navigator of the Ming Dynasty, built a far-reaching maritime trade network between China and Southeast Asian countries. Economic and trade cooperation opened a new chapter, and population mobility reached a peak in this period. Economic and trade exchanges have led to population mobility and cultural transmission — the influence of Han culture on Southeast Asian countries, the spread of Buddhism in China, and so on.

From the perspective of geographical nationality. Most of the overseas Chinese in Southeast Asia moved from $\mathrm{Fu}-$ jian, Guangdong, Hainan and Zhejiang in the early years. In addition, among the Southeast Asian countries bordering China, the same ethnic groups have different names: the Kachin people of Myanmar and the Jingpo people of Yunnan, the Thai people of Thailand and the Dai people of Yunnan, etc. These groups have the same customs and cultural background, have a strong sense of identity and innate affinity to the Han culture, and support the establishment of Confucius Institutes.

From a religious background. Thai people mostly believe in Buddhism; Indonesia, Malaysia, Brunei people mostly believe in Islam, and the Philippines is a Catholic country. The teachings of various religions are different, relatively speaking, Buddhism is more open and inclusive, the acceptance of various cultures is wider, and Buddhism has a long history of its introduction into China. Confucius Institutes carry out the spread of Chinese culture in Buddhist countries more easily accepted.

From the state support, Thailand is Southeast Asia to support the establishment of Confucius Institutes the largest country. Princess Sirindhorn, a member of Thailand's royal family, actively promoted humanistic exchange between China and Thailand. The royal family, which has a good public foundation and is respected by the Thai people, played a good role in promoting and promoting the guidance of national policies, which led to the rapid development of Confucius Institutes in Thailand. In 2006, the Chinese Affairs Office of China and the Ministry of Education of Thailand signed the Framework Agreement on Sino-Thai Chinese Teaching Cooperation. In the same year, Thailand established 10 Confucius Institutes, and the teaching of Chinese in Thailand changed rapidly from a form of civil organization to cooperation between the Chinese and Thai governments. ${ }^{[8]}$ Cultural identity, homology and national acceptance all have an impact on the distribution and number of Confucius Institutes, but the influencing factors are comprehensive, and it cannot be considered that a single factor has a significant impact on them.

\subsection{Conclusion of Friendly City Relations}

Because of China's proximity to Southeast Asian countries, both sides are rich in tourism resources, humanistic exchange have a long history, Coupled with the fact that early immigrants mostly moved to Southeast Asian countries, Therefore, Chinese cities and Southeast Asian countries naturally concluded friendly urban relations. According to statistics from the China Friendship Cities Federation, As of September 2019, China and the 11 nations of Southeast Asia have established 202 friendly cities, Thailand 40, Vietnam 38, Philippines 30, Indonesia 27, Cambodia 24, Laos 17, Malaysia 15, Myanmar 8, Brunei, Timor-Leste and Singapore, And China has established friendly city relations with Hanoi, Thailand, Manila, Indonesia, Phnom Penh, Vientiane, Myanmar, Rangoon, and Bandar Seri Begawan.

The development of friendly urban relations between China and Southeast Asian countries, on the one hand, mainly serves the economic cooperation and the opening of tourism resources between the two places. On the other hand, the two places are more abundant than the types of friendly cities between China and other regions because of their long history of humanistic exchange, religious beliefs and ancestral origin. It can be divided into political, historical, geographical, kinship and religion.

From a political point of view, some cities have important political and economic status in their respective countries, thus concluding friendly city relations. This category is first and foremost the friendly city relations established between the two capitals, such as Beijing, China, which has established friendly relations with the Indonesian capital Jakarta Special Zone, Bangkok, Hanoi, Manila, the Philippines and Vientiane, the Lao capital. In addition to the capitals of various countries, some central cities and important provinces and regions of China have also established friendly city relations with the central cities of other countries, such as Shanghai, Guangdong and Guangxi Zhuang Autonomous regions, which have successively established friendly city relations with Ho Chi Minh City, Vietnam.

Geographically, China has land borders with Vietnam, Laos and Myanmar in Southeast Asian countries, and the economic ties, personnel exchanges and the establishment of friendly cities on the land border between the two sides often play a mutually reinforcing role. The Guangxi Zhuang Autonomous Region has a land border with 
Vietnam, while Yunnan Province has a land border with Vietnam, Laos and Myanmar. Nine pairs of friendly cities have been concluded between the border cities of Guangxi Zhuang Autonomous region and Vietnam, four pairs of friendly cities have been established in the border cities of Yunnan Province and Vietnam, and two pairs of friendly cities have been established in the border cities of Yunnan Province and Laos. Yunnan Province and Myanmar border cities concluded two pairs of friendly cities.

Historically, on 2 June 2016, Fuzhou City, Fujian Province and Indonesia Sanbao Ridge City to form a friendly city. The conclusion of friendly city relations between the two cities is related to the navigation of Chinese navigator Zheng He. When Zheng He first went west, landed and traded on 30 June 1406 in Sanbao Ridge, Java, Sanbao Ridge City is also named for this. Changle City, a subsidiary of Fuzhou City, is the anchor of Zheng He's voyage to the West, Zheng He was in the Ming Dynasty Xuande six years (AD 1431) in the territory of Changle Tianfei Palace set up "Tianfei Ling Ying Ji" tablet, to record the purpose and significance of the voyage, The first six Western passes, achievements and the seventh Western mission. Zheng He's great voyage to the West, So that Zheng He in Fuzhou, Fujian Province, Changle City and including Indonesia, Malaysia and other Southeast Asian countries by the local people as gods, and thus formed the "Zheng He belief ". ${ }^{[9]}$ Sanbao Ridge is the third largest port in Indonesia. There are two temples commemorating Zheng He, namely," Sanbao Palace "and" Da Jue Temple ". Every year on June 29(or 30) of the lunar calendar, Sanbao is the day of inspection (some people call it Sanbao birthday). On this day, people carried the statue of Zheng He parade, symbolizing Zheng He out of the cave patrol. After Fuzhou became an important node city of the Maritime Silk Road in the 21st century, in August 2014, the Fujian Provincial delegation held economic and trade tourism promotion and business reception and cultural performances in Sanbao Ridge, Indonesia, to deepen economic and trade and humanistic exchange between the two places. ${ }^{[10]}$

In terms of kinship, the city is the most friendly city in Malaysia and China. It is also the most concentrated area of overseas Chinese in Fuzhou, about $80 \%$ of the local overseas Chinese, and about 70,000 Chinese and overseas Chinese from Gutian and Pingnan in Ningde City gathered in Shi Wu. Locals speak Fuzhou (Minqing), Among the merchants in the city ,90\% are Chinese (mainly descendants of Fuzhou Minqing and Gutian). These factors make up the psychological situation of the Chinese, so that they recognized their mother tongue (Fuzhou) and Mandarin in language and literature, Formed a unique cultural foundation. Qinghe County, Hebei Province is considered the or- igin of the Zhang clan, the overseas population of Zhang is over 20 million, Malaysia is the majority of Shiwu City. "There are now more than 40,000 overseas Chinese of Guangning nationality in Shiwu City, Is the overseas Guangning Chinese overseas Chinese most concentrated area, With the Malaysian Shivu Guangning Association in the city of Shivu, And the original mayor of Shiwu City award of the ancestors of the Han Dynasty is also Guangning County, Driven by the Canton Ning guild, The two cities were able to establish friendly urban relations. " [9]

In religion, Buddhist culture has become an important factor in promoting the establishment of friendly relations between China and Southeast Asian cities. In addition to the cities of Yun and Gui provinces, the only friendly city relationship between Myanmar and other provinces in China is Yangon and Yangzhou City, Jiangsu Province. The friendly city relationship between the two cities is due to the Buddhist culture of the two places. Yangzhou is an important area for the development and spread of Chinese Buddhism. In July 1995, Yangon City Mayor Angkor Li led a delegation to visit Yangzhou, visit Daming Temple, learned that the new Qiling Tower to invite jade Buddha worship, immediately said to give five jade Buddha. Jade Buddha arrived at Daming Temple from Shanghai Port on April 29,1996, and then Yangzhou and Myanmar established friendly city relations on July 8,1997.

Based on the above several aspects, although China and Southeast Asian countries concluded friendly urban relations late, but the prospects are considerable, but also because of geopolitical, economic cooperation space, rich tourism resources and a long history of humanistic exchange and other factors and rapid development. As far as the current development is concerned, the overall power gap between China and Southeast Asian countries is widening, and under the combined influence of non-traditional security disputes such as the overseas Chinese issue, the South China Sea territorial dispute, the exploitation of resources, and the "China Threat Theory ", the negative factors of cooperation between the two sides are expanding. ASEAN countries are concerned that they are at a disadvantage in their relations with China, that doubts and guard against China still exist or even strengthen, that differences are magnified, and that cooperation in political security is affected. ${ }^{[1]}$

\subsection{Rich Tourism Resources}

Tourism is an activity between tourist destination and tourist destination through tourist passage. According to the characteristics of modern transportation, it is directly manifested as the flow of tourists between cities and the convenience of inter-city communication. In cross-border 
tourism activities, the interaction ability and cooperation level between cities are the key to influence and restrict the level of tourism development. ${ }^{[12]}$ Southeast Asia is located in a superior geographical location, pleasant climate, sunny. Moreover, Southeast Asia has rich natural resources advantages, high-quality beaches, islands and primitive tropical jungles, a wide variety of animal and plant resources, let tourists forget to return. In the past ten years, China and ASEAN tourism cooperation has made rapid progress. According to the ASEAN secretariat, the number of Chinese tourists visiting ASEAN countries in 2016 was 20339261, more than five times that of 2007 (see Figure 4).

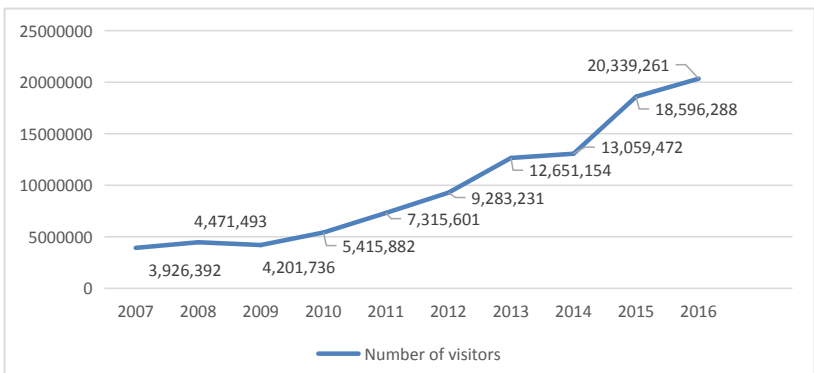

Figure 4. Chinese mainland Number of visitors to ASEAN countries (2007-2016) ${ }^{[13]}$

China and ASEAN are important tourist destinations and tourist destinations, and China is the largest foreign tourist destination in ASEAN. Tourism cooperation in 2017 has become a key area of China-ASEAN cooperation. In March 2017, China and ASEAN officially launched the "China-ASEAN Tourism Cooperation Year ". Around tourism cooperation, China and ASEAN have launched a series of exchanges and cooperation. In addition, tourism facilitation services are also in full swing, Asian airlines and other airlines have increased routes for China and ASEAN countries, and countries such as the Philippines have introduced visa facilitation and preferential policies for Chinese tourists. The number of Chinese tourists traveling to ASEAN countries has further increased. In terms of inbound tourism, Myanmar, Vietnam, Malaysia and the Philippines of ASEAN countries entered the top ten tourist countries in the 2017 Chinese foreign inbound tourism market. ${ }^{[14]}$

In addition to rich natural resources, superior geographical location and government policy support, tourism in Southeast Asia is greatly influenced by religious culture, among which the representative is Mazu culture.

Mazu culture is one of the most recognized cultures of overseas Chinese. According to relevant statistics, Mazu has more than 300 million believers in the world. Among the believers, overseas Chinese are an important part. ${ }^{[15]}$ At present, Mazu culture has been spread and developed in many overseas countries, and occupies an irreplaceable position in the tourism industry of some Southeast Asian countries, which brings surprises to the tourism industry income of these countries every year. Among Southeast Asian countries, Malaysia, Singapore, the Philippines and Thailand are more representative.

Based on the above analysis, we can travel is an indispensable part of the construction of the "21st Century Maritime Silk Road ", is a "people's hearts and minds" project, in the "Belt and Road" interconnection has the advantage of connecting first and first.

\section{Thoughts on Further Deepening the Hu- manistic Exchange between China and South- east Asia}

In a speech to Indonesia's parliament in October 2013, President Xi Jinping pointed out that China-ASEAN relations are at a new historical starting point and that China is willing to work together with ASEAN countries to make the two sides "good neighbors, good friends and good partners ", to build a closer "China-ASEAN destiny community" and to jointly build the "Maritime Silk Road" in the 21 st century. ${ }^{[16]}$ Especially under the background of the deterioration of China's surrounding environment, activating the common memory of China and Southeast Asian countries through Zheng he's voyage to the West and reshaping the friendly relations between China and Southeast Asian countries by the "Maritime Silk Road" in the 21 st century will become an important way for both sides to communicate values and deepen mutual trust and cooperation. In 2011, the China-ASEAN Center was formally established as an important service platform to promote exchanges and cooperation in economic, trade, education, tourism and culture. China is willing to further strengthen social and humanistic exchange with ASE$\mathrm{AN}$, jointly promote exchanges in the fields of tourism, education, culture, media and youth, and make use of the China-ASEAN Center, Education Exchange Week, Youth Camp and other platforms to continuously enhance folk understanding and friendship, so that the people of both sides can become firm supporters, active builders and real beneficiaries of China-ASEAN relations.

In a word, in China's exchanges with Southeast Asian countries, a word "harmony" runs through all the time, which not only contains the feat of Zheng he's seven voyages to the West and the opening up of the "Maritime Silk Road ", but also reflects the objective facts of harmony and symbiosis between the two sides for thousands of years. There are differences in development level, social system, ideology, culture and religion between China and 
Southeast Asian countries, with outstanding diversity, but we have geographical advantages, historical, cultural and even blood advantages. We should make use of these resource advantages, seize the opportunity, and jointly construct a new pattern of humanistic exchange between the two sides.

\section{Fund Project}

This paper is the Project of the 4th "Mentor Academic Leadership Project" of Shanghai International Studies University- "A Comparative Study of Humanistic Exchange and Cooperation between China and Southeast Asian in the Perspective of 'the Belt and Road' Initiative" (2020114240); the general project of the National Social Science Fund of China- "Research on 'the Belt and Road' and Partnership Development in China's Xinjiang Surrounding Countries" (18BGJ020); the project of Center for Regional and Country Studies, Ministry of Education- "Research on the Internal Mechanism of Islamic Cooperation Organization" (17GQYH01); the project of Connotation Construction of Think Tanks in Universities of Shanghai- "Risk Factors of Religious Extremism in the Intersection Area of 'the Belt and Road "'(2019SL01) milestones.

\section{References}

[1] Foreign Ministry Official Website :" Joint Declaration of Leaders of the People's Republic of China and ASEAN Countries — Strategic Partnership for Peace and Prosperity", 1 October 2003, https:// www.fmprc.gov.cn/web/wjb_673085/zzjg_673183/ yzs_673193/dqzz_673197/dnygjlm_673199/ zywj_673211/t27721.shtml, Last visit date: June 15, 2019.

[2] Press Office of the State Council of the People's Republic of China ," China-ASEAN close human exchanges and cooperation to consolidate the foundation of bilateral friendship ", About 12 December 2011, http://www.scio.gov.cn/m/zhzc/35353/35354/ Document/1508370/1508370.htm, Last visit date: June 16,2019.

[3] "China TV series into ASEAN: China-ASEAN humanistic exchange in depth ", On 24 September 2012, http://news.163.com/12/0924/17/8C6D5LRS00014JB5.html, Last visit date: June 16,2019.

[4] China News Network :" Building China-ASEAN Neighbourliness and Friendship Cultural Values Helps Regional Stability ", On 18 November 2011, http://www.chinanews.com/gj/2011/11-18/3471449. shtml, Last visit date: June 16,2019.

[5] Chen Wanling et al. Maritime Passage __ Maritime
Silk Road in the 21st Century. Chongqing: Chongqing University Press, September 2018, p .110.

[6] Confucius Institute headquarters / National Han Office: http://www.hanban.org/confuciousinstitutes/ node_10961.htm, final visit date: June 14,2019.

[7] Confucius Institute headquarters / National Han Office: http://www.hanban.org/confuciousinstitutes/ node 10961.htm, final visit date: June 18,2019.

[8] He Wenzhu, The Development Model and Optimization Strategy of Confucius Institutes in Thailand, Journal of Yunnan Normal University (Teaching and Research Edition of Chinese as a Foreign Language), July 2016, p.84.

[9] Li Jing: An Analysis of the Status of the Conclusion of Friendly City Relations between China and Southeast Asian Countries. Southeast Asia Vertical and Vertical, No .4,2017, p .43-44.

[10] Fuzhou delegation to Indonesia to promote economic and trade tourism, August 23,2014, http://news. fznews.com.cn/zhengwu/2014-8-23/2014823OJvUIxO0GF141417.shtml, final visit date: June 30,2019 .

[11] He Shengda, Strategic Patterns in Southeast Asia and China-ASEAN Relations, Southeast Asia Research, No .1,2014, pp .1-10.

[12] Zhao Jianjun. Difficulties and Countermeasures of the Friendly City Mechanism in the Construction of the Southern Silk Road Tourism Belt. Journal of Dali University, September 2018, p .118.

[13] Data source: ASEAN Secretariat: http://www. $\mathrm{scio.gov.cn} / \mathrm{m} / \mathrm{zhzc} / 35353 / 35354 / \mathrm{Docu}$ ment/1508370/1508370.htm0.

[14] " $<$ China outbound tourism development annual report 2018> public release, June 27, 2018, http:// www.scio.gov.cn/m/zhzc/35353/35354/Document/1508370/1508370.htm1 final visit date: June 30,2019 .

[15] Lin Ming-tai, Lian Chenxi, Zhao Xiangxiang. A Joint Analysis of Mazu Cultural Tourism Development in Major countries along the Maritime Silk Road. Journal of Wuyi University, May 2018, p .64.

[16] Xi Jinping, Working Together to Build China-ASEAN Destiny Community — Speech in Indonesian Parliament, People's Daily, October 4,2013,2nd ed.

\section{Author's Brief Introduction}

Wen Zhihong ,1992 , female, native to Yixing City, Jiangsu Province, Ph.D. in International Relations, School of International Relations and Public Affairs, Shanghai International Studies University, a member of the Southeast Asia Research Group of Institute of Silk Road Strategy Studies . 